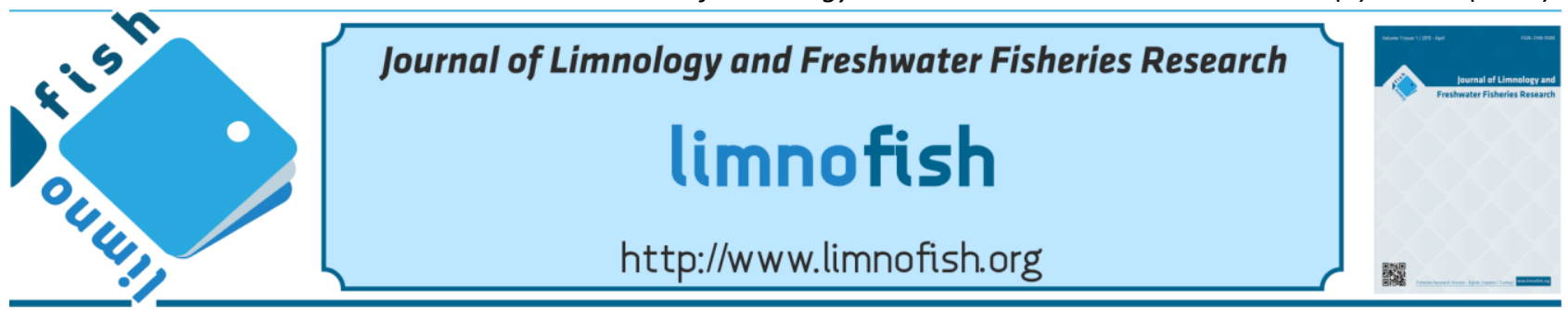

\title{
Variations of Some Growth Characteristics and Length-Length Relationships of Sakarya Bleak (Alburnus esherichii Steindachner, 1897) in Different Habitats
}

\author{
Soner ÇETINKAYA ${ }^{1, *}$, Vedat YEĞEN ${ }^{1}$, Fuat BILGIN ${ }^{1}$, Rahmi UYSAL ${ }^{1}$, Hasan BOSTAN ${ }^{2}$ \\ ${ }^{1}$ Fisheries Research Station, 32500 Eğirdir, Isparta-Türkiye \\ ${ }^{2}$ Ministry of Food, Agriculture and Livestock, County Directorate, 33640 Anamur, Mersin-Türkiye
}

\section{A BSTRACT}

In this study, some growth characteristics and relationships of Sakarya bleak inhabiting different water habitats (dam, pond and creek) in the Bilecik Province of Türkiye were examined. Sample weights ranged from 0.17 to $111.25 \mathrm{~g}$. Total lengths were measured between 2.70 and $19.80 \mathrm{~cm}$. According to the localities, the $b$ values varied between $2.9469 \pm 0.07$ and $3.2548 \pm 0.03$. $R^{2}$ values were computed between 0.850 and 0.996 . The relative condition factor values were similar to each other, while the Fulton's condition factor values ranged from $0.79 \pm 0.01$ to $1.29 \pm 0.03$. The length-weight $(L W R)$ and length-length relationships (LLRs) of samples were examined. According to localities, growth type of the length - weight relationships were either isometric or positive allometric.

Keywords: Fulton's condition factor, isometric, growth, positive allometric, Sakarya bleak

\section{ARTICLE INFO}

RESEARCH ARTICLE

Received : 11.012015

Revised : :11.03.2015

Accepted : 19.03.2015

Published : 20.04.2015

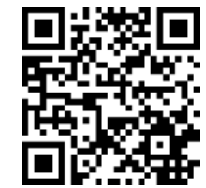

* CORRESPONDING AUTHOR

cetinson_70@hotmail.com

Tel : +902463133460

Fax: +902463133463

İnci Balığı (Alburnus escherichii Steindachner, 1897)'nın Farklı Habitatlarda Bazı Büyüme Özellikleri ve Boy-Boy İlişkilerinin Değişimi

Öz: $\mathrm{Bu}$ çalışmada Bilecik ilindeki farklı su kaynaklarında (baraj, gölet ve dere) dağılım gösteren inci balı̆̆ (Alburnus escherichii Steindachner, 1897)'nın büyüme özellikleri ve ilişkileri çalışılmıştır. Örneklerin ağırlıkları 0,17 ile 111,25 g, arasında değişmiştir. Toplam boyları 2,70 - 19,80 cm arasında ölçülmüştür. Lokalitelere göre $b$ değerleri $2.9469 \pm 0.07-3,2548 \pm 0,03$. arasında değişmiştir. $R^{2}$ değerleri 0,850 - 0,996 arasında hesaplanmıştır. Oransal kondisyon faktörü değerleri birbirine benzer bulunurken Fulton kondisyon faktörü değerleri $0,79 \pm 0,01-1,29 \pm 0,03$ arasındadır. Örneklerin boy-ağırlı $\left(W=a L^{b}\right)$ ve boy-boy $(T L=a+S L b)$ ilişkileri çalışılmıştır. Lokalitelere göre balıklar izometrik ve pozitif allometrik büyüme özelliği göstermiştir.

Anahtar kelimeler: Fulton kondisyon faktörü, izometrik, büyüme, pozitif allometrik, İnci balığ1

\section{Introduction}

The most inhabited area for Alburnus species is Türkiye with 20 species among total of 41 species (Özuluğ and Freyhof 2007). Sakarya bleak (Alburnus escherichii Steindachner, 1897) inhabits in the Büyükmenderes river (Y1lmaz et al. 2003), Sakarya and Kizilırmak rivers, Filyos, Bayındır-Yalımkaya, Karafasıl creeks (İlhan and Balık 2008), Çamlıdere, Kirmir creeks and Mogan lake (Innal et al. 2007), Gelingüllü dam (Kırankaya and Ekmekçi 2007), and Kunduzlar dam (Özbek and Öztürk 2010). Sakarya bleak is a small bodied Cyprinid with silver color (Bogutskaya 1997; Geldiay and Balık 2007) (Figure 1).

The fish growth can show variations depending to the waters in which they live. Those can be found by various methods. For this purpose, length-weight $(L W R)$ and length-length relationships $(L L R s)$, and condition factor of fish are utilized to elucidate the differences in growth (Y1lmaz et al. 2010).

The length weight relationship is very important to determine the sustainable utilization and management of fish populations (Pervin and Mortuz 2008). The length-weight relationship is used to determine fish condition and somatic growth form (i.e. isometric or allometric) (Le Cren 1951; Ricker 1975). The fish weight and biomass can be determined using the length-weight relationship in the presence of length data only (Le Cren 1951; Koutrakis and Tsikliras 2003). The length-length relationship is especially important 
when compared the studies made with using different lengths values (Moutopoulos and Stergiou 2002).

The $L W R$ and LLRs and condition factors of freshwater fish associated with a number of studies have been carried out previously (Alp and Kara 2004; Bostanc1 et al. 2007; Y1lmaz et al. 2007; Kırankaya and Ekmekçi 2007; Bostancı et al. 2009; Tarkan et al. 2009). Nevertheless, there are no adequate studies on growth features of Sakarya bleak. Innal (2010) studied on population structure and some growth characteristics of the species. So, in this study, the determination of length-weight, length-length and condition factors values of Sakarya bleak were aimed. Also, it was aimed comparing the growth and length relationships with obtained data from different water sources.

\section{Materials and Methods}

The Bilecik Province selected as the study area is located in the Marmara region of Türkiye. The samples of Sakarya Bleak which reported its presence in Türkiye (Kuru 2004; Fricke et al. 2007; Geldiay and Balık 2007) were found in Dodurga and Kizıldamlar dams, Borçak, Ertuğrulgazi, Kurtköy, Küçükelmalı, Pelitözü and Zemzemiye ponds, Göksu, Karasu and Dipsiz creeks in the Bilecik province (Figure 2).

The study was carried out as single sampling in all sampling sites in May-August 2010. The samples obtained with various mesh sizes of gill nets $(16 \times 16$, $20 \times 20,25 \times 25,30 \times 30,40 \times 40$ and 50x50 mm) and beach seine were transported in formalin solution $(4 \% v / v)$ to Eğirdir Fisheries Research Station laboratory, then the weights and lengths of them were measured. Total, standard and fork lengths ( $T L, S L$, $F L)(\mathrm{cm})$ were measured by using measuring board (nearest to $1 \mathrm{~mm}$ ) and body weight (g) was taken on a digital balance with $0.01 \mathrm{~g}$ accuracy. The $L W R s$, $L L R s$, Fulton's condition factor $(K)$ and relative condition factor $(K n)$ were determined for obtained samples in Dodurga and Kizıldamlar dams, Ertuğrulgazi, Kurtköy, Küçükelmalı, Pelitözü ponds and Karasu creek.

The LWRs were examined;

$W=a L^{b}$

formula (W= weight $(\mathrm{g}) ; \quad L$ : total length $(\mathrm{cm})$; $a=$ constant $b=$ constant) (Bagenal and Tesch 1978).

LLRS were examined; formulas, where $a, b$ are constants values obtained by linear regression (Y1lmaz et al. 2010).

To compare the obtained samples from different localities condition factors (Fulton's condition factor);

\section{$K=100 \mathrm{~W} / \mathrm{L}^{3}$ (Simon and Mazlan 2008)}

and relative condition factor;

$K n=W / W^{\prime}($ Le Cren 1951).

$W=$ weight $(\mathrm{g}) ; L=$ total length $(\mathrm{cm}), W^{\prime}=$ calculated weight from LWRs were used. The $t$ test $(t t)$ was used for determination of growth type. Differences between condition factor, and relative condition factor in the all localities were tested by analysis of variance (ANOVA).

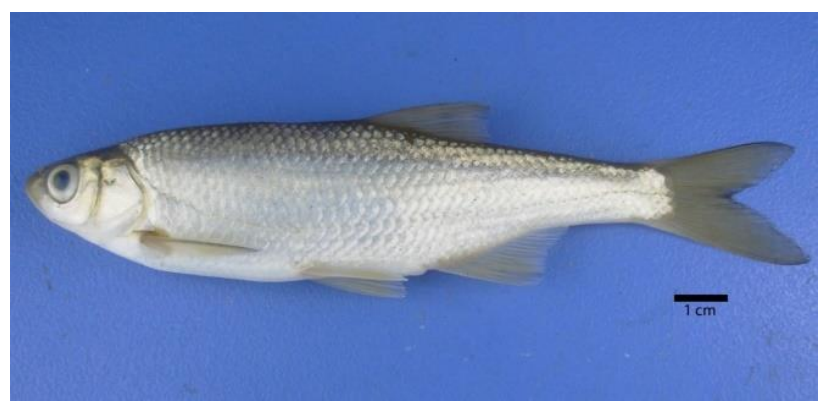

Figure 1. Sakarya bleak (Alburnus escherichii Steindachner, 1897) Küçükelmalı Pond-Bilecik (the original photo taken by Dr. Vedat Yegen).

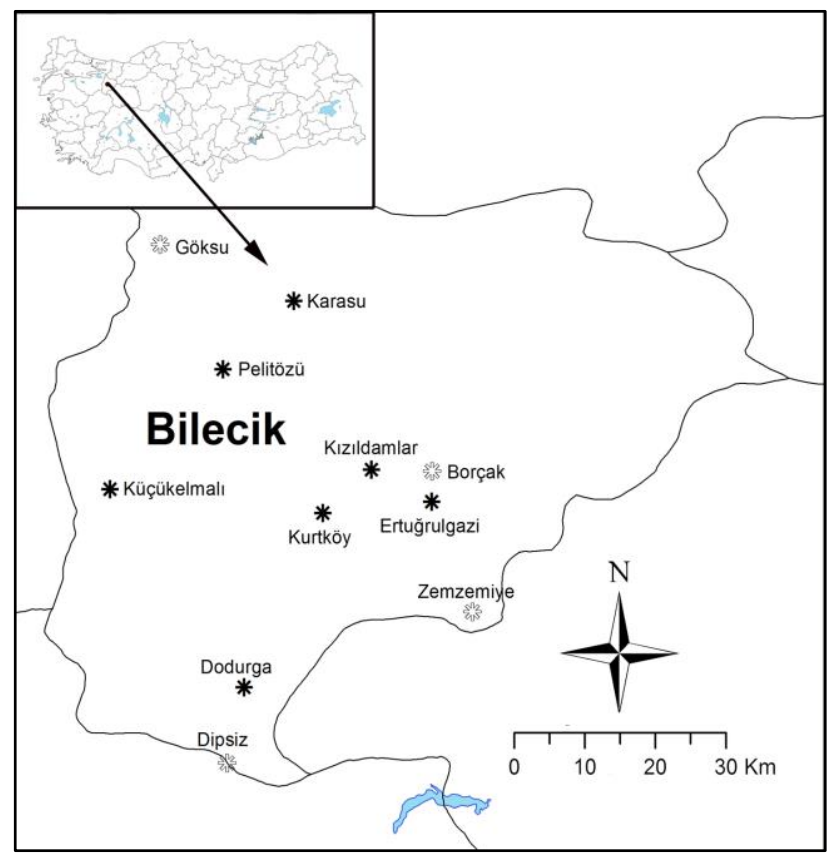

Figure 2. Study areas (Dodurga and Kızıldamlar dams, Borçak, Ertuğrulgazi, Kurtköy, Küçükelmalı, Pelitözü and Zemzemiye ponds, Göksu, Karasu and Dipsiz creeks). 


\section{Results}

Weight and length values obtained in the study are presented in Table 1 . The weight values in the all localities changed between $0.17 \mathrm{~g}$ to $111.25 \mathrm{~g}$. The length values (total, fork, and standard) were measured as from 2.70 to $19.80 \mathrm{~cm}$, from 2.50 to $18.30 \mathrm{~cm}$ and from 2.30 to $17.00 \mathrm{~cm}$, respectively.
The parameters of $L W R s$ and their graphics are given in Table 2 and Figure 3, respectively. The determined equations for length-length relationships are given in Table 3. The equations provide a comparison with other studies performed by different lengths. The Fulton's and relative condition factors are given in Table 4.

Table 1. The minimum, maximum and mean weight and length values of Sakarya bleak.

\begin{tabular}{|c|c|c|c|c|c|}
\hline & & $W(\mathrm{~g})$ & $T L(\mathrm{~cm})$ & $F L(\mathrm{~cm})$ & $S L(\mathrm{~cm})$ \\
\hline Locality & $n$ & $\begin{array}{l}\text { Mean } \pm S E \\
(\text { Min-Max) }\end{array}$ & $\begin{array}{l}\text { Mean } \pm S E \\
(\text { Min-Max) }\end{array}$ & $\begin{array}{l}\text { Mean } \pm S E \\
(\text { Min-Max) }\end{array}$ & $\begin{array}{l}\text { Mean } \pm S E \\
(\text { Min-Max) }\end{array}$ \\
\hline Dodurga & 18 & $\begin{array}{c}73.52 \pm 4.26 \\
(44.51-111.25)\end{array}$ & $\begin{array}{c}17.74 \pm 0.30 \\
(15.20-19.80)\end{array}$ & $\begin{array}{c}16.34 \pm 0.28 \\
(14.00-18.30)\end{array}$ & $\begin{array}{c}15.06 \pm 0.28 \\
(12.70-17.00)\end{array}$ \\
\hline Ertuğrulgazi & 50 & $\begin{array}{c}4.56 \pm 0.36 \\
(0.20-9.89)\end{array}$ & $\begin{array}{c}7.63 \pm 0.30 \\
(3.00-10.40)\end{array}$ & $\begin{array}{c}6.91 \pm 0.27 \\
(2.80-9.60)\end{array}$ & $\begin{array}{c}6.27 \pm 0.25 \\
(2.50-8.70)\end{array}$ \\
\hline Karasu & 18 & $\begin{array}{c}16.18 \pm 2.06 \\
(7.43-41.85)\end{array}$ & $\begin{array}{c}11.52 \pm 0.41 \\
(9.40-16.00)\end{array}$ & $\begin{array}{c}10.43 \pm 0.39 \\
(8.70-14.70)\end{array}$ & $\begin{array}{c}9.37 \pm 0.35 \\
(7.50-13.30)\end{array}$ \\
\hline Kizıldamlar & 50 & $\begin{array}{c}10.89 \pm 1.63 \\
(0.17-44.25)\end{array}$ & $\begin{array}{c}9.15 \pm 0.55 \\
(2.80-15.90)\end{array}$ & $\begin{array}{c}8.29 \pm 0.50 \\
(2.50-14.60)\end{array}$ & $\begin{array}{c}7.56 \pm 0.46 \\
(2.30-13.20)\end{array}$ \\
\hline Kurtköy & 52 & $\begin{array}{c}23.52 \pm 2.42 \\
(0.18-55.59)\end{array}$ & $\begin{array}{c}11.57 \pm 0.72 \\
(3.00-16.60)\end{array}$ & $\begin{array}{c}10.42 \pm 0.65 \\
(2.70-14.90)\end{array}$ & $\begin{array}{c}9.40 \pm 0.59 \\
(2.50-13.80)\end{array}$ \\
\hline Küçükelmalı & 25 & $\begin{array}{c}14.62 \pm 3.73 \\
(0.35-50.90)\end{array}$ & $\begin{array}{c}9.05 \pm 0.91 \\
(3.50-16.40)\end{array}$ & $\begin{array}{c}8.29 \pm 0.85 \\
(3.20-15.20)\end{array}$ & $\begin{array}{c}7.58 \pm 0.78 \\
(3.00-13.90)\end{array}$ \\
\hline Pelitözü & 50 & $\begin{array}{c}2.59 \pm 0.20 \\
(0.17-6.61)\end{array}$ & $\begin{array}{c}6.64 \pm 0.19 \\
(2.70-9.30)\end{array}$ & $\begin{array}{c}5.94 \pm 0.17 \\
(2.50-8.30)\end{array}$ & $\begin{array}{c}5.31 \pm 0.15 \\
(2.39-7.50)\end{array}$ \\
\hline
\end{tabular}

Table 2. The length-weight relationships parameters of Sakarya bleak.

\begin{tabular}{lcccccc}
\hline Locality & $n$ & $a$ & $b \pm S E$ & $R^{2}$ & $t_{\mathrm{t}^{*}}$ & Growth type $^{* * *}$ \\
\hline Dodurga & 18 & 0.0075 & $3.1879 \pm 0.33$ & 0.850 & $0.56^{\mathrm{a}}$ & $i$ \\
Ertuğrulgazi & 50 & 0.0069 & $3.1011 \pm 0.03$ & 0.995 & $3,26^{\mathrm{b}}$ & $a+$ \\
Karasu & 18 & 0.0080 & $3.0893 \pm 0.17$ & 0.956 & $0.52^{\mathrm{c}}$ & $i$ \\
Kızıldamlar & 50 & 0.0065 & $3.1333 \pm 0.03$ & 0.996 & $4.53^{\mathrm{d}}$ & $a+$ \\
Kurtköy & 52 & 0.0049 & $3.2548 \pm 0.03$ & 0.996 & $8.77^{\mathrm{e}}$ & $a+$ \\
Küçükelmalı & 25 & 0.0058 & $3.2425 \pm 0.03$ & 0.998 & $7.26^{\mathrm{f}}$ & $a+$ \\
Pelitözü & 50 & 0.0086 & $2.9469 \pm 0.07$ & 0.971 & $-0.73^{\mathrm{g}}$ & $i$
\end{tabular}

${ }^{*} t t=\mathrm{t}$ test value, $t T 0.05=$ table value, a, $(t t<t T 0.05,17=1.73)$; b, $(t t>t T 0.05,49=1.68) ; \mathrm{c},(t t<t T 0.05,17=1.73) ; \mathrm{d},(t t>t T 0.05,49=1.68) ;$ $\mathrm{e},(t t>t T 0.05,51=1.68) ; \mathrm{f},(t t>t T 0.05,24=1.71) ; \mathrm{g},(t t<t T 0.05,49=1.68)$.

$* * i=$ isometric growth; $a+=$ positive allometric. 
Table 3. The length-length relationships of Sakarya bleak.

\begin{tabular}{lccccccc}
\hline Locality & $n$ & $T L-F L$ & $R^{2}$ & $F L-S L$ & $R^{2}$ & $S L-T L$ & $R^{2}$ \\
\hline Dodurga & 18 & $0.402+1.061 F L$ & 0.976 & $1.169+1.007 S L$ & 0.987 & $-0.636+0.884 T L$ & 0.962 \\
Ertuğrulgazi & 50 & $0.048+1.096 F L$ & 0.998 & $1.102+1.087 S L$ & 0.997 & $-0.103+0.835 T L$ & 0.996 \\
Karasu & 18 & $0.424+1.064 F L$ & 0.992 & $0.295+1.082 S L$ & 0.987 & $-0.495+0.856 T L$ & 0.992 \\
Kızıldamlar & 50 & $0.098+1.091 F L$ & 0.998 & $0.055+1.090 S L$ & 0.999 & $-0.105+0.838 T L$ & 0.997 \\
Kurtköy & 52 & $-0.009+1.111 F L$ & 0.999 & $0.028+1.105 S L$ & 0.998 & $-0.009+0.813 T L$ & 0.998 \\
Küçükelmalı & 25 & $0.120+1.077 F L$ & 0.999 & $0.035+1.090 S L$ & 0.999 & $-0.125+0.851 T L$ & 0.999 \\
Pelitözü & 50 & $0.065+1.107 F L$ & 0.983 & $0.126+1.096 S L$ & 0.991 & $-0.030+0.803 T L$ & 0.976 \\
\hline
\end{tabular}
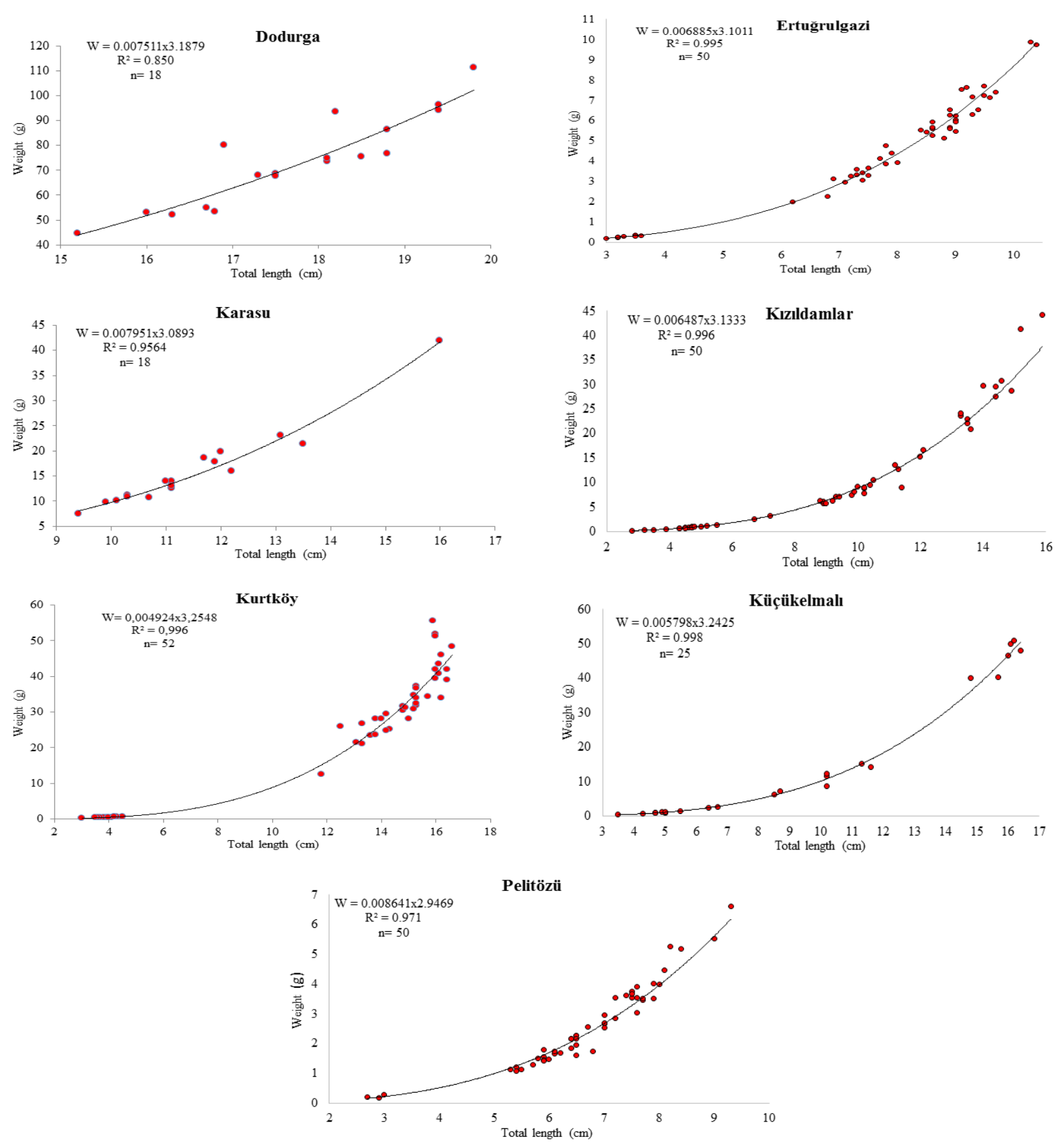

Figure 3. The length-weight relationships of Sakarya bleak. 
The Fulton's condition factors were determined as minimum in the Pelitözü pond as $0.79 \pm 0.01$, in the Ertuğrulgazi pond as $0.87 \pm 0.01$, and in the Kizıldamlar dam as $0.87 \pm 0.01$, and as maximum in the Dodurga dam as $1.29 \pm 0.03$ (Table 4). The relative condition factors were determined same as to each other. According to the localities, the $b$ values were similar except for Pelitözü pond (Figure 4). It was not found any statistical difference among $K n$ values in all sampling sites $(p<0.05)$ (Table 4 , Figure 5).

Table 4. The Fulton's and relative condition factors of Sakarya bleak.

\begin{tabular}{|c|c|c|c|c|c|}
\hline Localities & $n$ & $K \pm S E$ & (Min-Max) & $K n \pm S E$ & $($ Min-Max $)$ \\
\hline Dodurga & 18 & $1.29 \pm 0.03^{\mathrm{d}}$ & $(1.12-1.66)$ & $1.00 \pm 0.02^{\mathrm{a}}$ & $(0.88-1.30)$ \\
\hline Ertuğrulgazi & 50 & $0.84 \pm 0.01^{\mathrm{ab}}$ & $(0.68-1.00)$ & $1.01 \pm 0.01^{\mathrm{a}}$ & $(0.86-1.18)$ \\
\hline Karasu & 18 & $0.99 \pm 0.02^{\mathrm{c}}$ & $(0.87-1.16)$ & $1.01 \pm 0.02^{\mathrm{a}}$ & $(0.87-1.17)$ \\
\hline Kızıldamlar & 50 & $0.87 \pm 0.01^{\mathrm{ab}}$ & $(0.60-1.17)$ & $1.00 \pm 0.01^{\mathrm{a}}$ & $0.67-1.26)$ \\
\hline Kurtköy & 52 & $0.90 \pm 0.03^{\mathrm{bc}}$ & $(0.56-1.38)$ & $1.01 \pm 0.02^{\mathrm{a}}$ & $(0.80-1.42)$ \\
\hline Küçükelmalı & 25 & $0.97 \pm 0.03^{c}$ & $(0.79-1.23)$ & $1.00 \pm 0.02^{\mathrm{a}}$ & $(0.79-1.13)$ \\
\hline Pelitözü & 50 & $0.79 \pm 0.01^{\mathrm{a}}$ & $(0.55-1.07)$ & $1.01 \pm 0.02^{\mathrm{a}}$ & $(0.71-1.32)$ \\
\hline
\end{tabular}

* Values in the same column with same lowercase are statistically equal $(p>0.05)$.

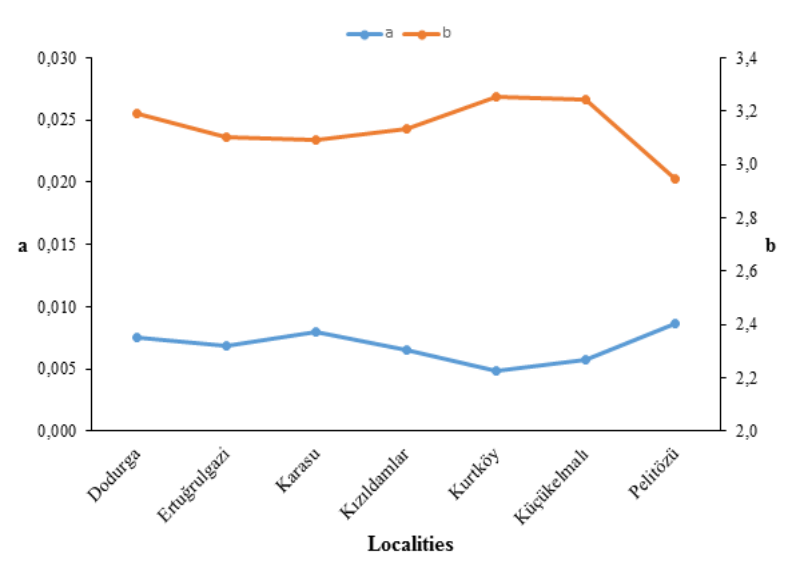

Figure 4. Changing the $a$, and $b$ values according to the localities.

\section{Discussion}

The analysis of length-weight values lead to two different objects, first of which is the relationship between length and weight values may be converted to each one to other, and second one is to determine expected weight for length and indications of general specialization of growth of fish like as fatness or general well-being, etc. (Le Cren 1951). As anticipated, $b$ constants were changed from 2.5 to 3.5 (Soomro et al. 2007). According to the $t$ test results,

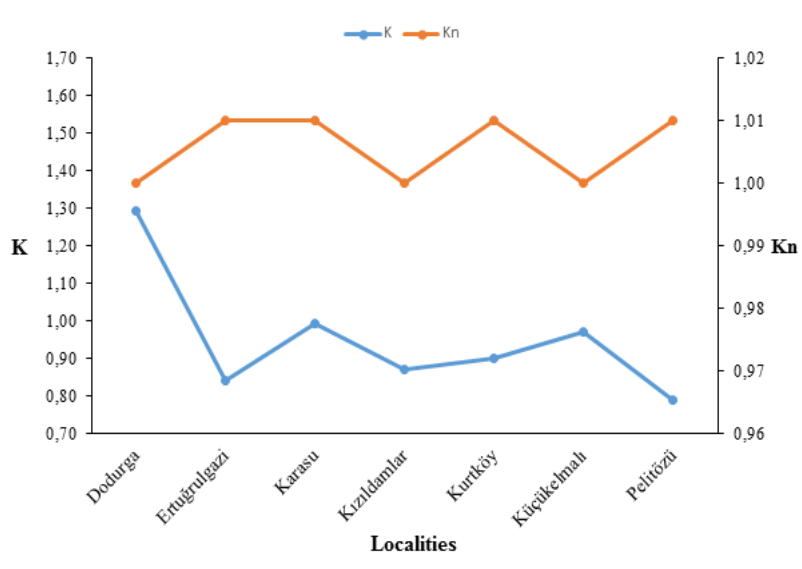

Figure 5. Changing the $K$, and $K n$ values according to the localities.

the samples of Dodurga dam, Pelitözü pond and Karasu creek showed isometric growth characteristics. Also, obtained samples in Kızıldamlar dam, Ertuğrulgazi, Kurtköy, and Küçükelmalı ponds indicated positive allometric growth characteristics. Bagenal and Tesch (1978) reported those changes may be due to season, habitat, gonadal maturity, sex, stomach fullness, health and preservation techniques. We thought that, the Fulton's condition factors were low because of the 
effect of over sport fishing in the Kizildamlar dam, Ertuğrulgazi, and Pelitözü ponds. In contrast, when evaluating the relative condition factors of fish according to the localities it were not determined any differences. The changes in $a$, and $b$ values for the localities were given in Figure 4. It was determined negative meaningful correlation between $a$, and $b$ values according to the localities $(r=-0.855 ; p<0.05)$. There were not differences in the values of Dodurga dam samples because maybe there is not overfishing pressure, exploitation or predation. In a study carried out in the Camkoru pond (in Ankara-Türkiye) the weight values were changing between 7.1 to $56.8 \mathrm{~g}$, and the length values were between $7.5-16.4 \mathrm{~cm}$, also the length-weight equation determined as $W=0.0066 L F^{3.2501}$ (Innal 2010). In that study, the gill nets with various mesh sizes were used for obtaining samples, while we used gill nets and beach seine. The differences were seen in the obtained values, it is maybe because of differences in the samples catching tools.

\section{Acknowledgements}

The samples used in this study were obtained in the sampling area of study for Eğirdir Fisheries Research Station TAGEM/HAYSUD/2006/05/01 Project of Ministry of Food, Agriculture and Livestock of Türkiye.

\section{References}

Alp A, Kara C. 2004. Length, weight and condition factors of the native brown trouts (Salmo trutta macrostigma Dumeril, 1858 and Salmo platycephalus Behnke, 1968) in the Ceyhan, Seyhan and Euphrates basins. Ege J Fish Aqua Sci. 21(1-2):9-15. [in Turkish]

Bagenal TB, Tesch, FW. 1978. Age and growth. In: Bagenal TB, editor. Methods for Assessment of Fish Production in Freshwaters. Oxford: Blackwell Science Publication. p. 101-136.

Bogutskaya NG. 1997. Contribution to the knowledge of leuciscine fishes of Asia Minor. Part 2. An annotated check-list of leuciscine fishes (Leuciscinae, Cyprinidae) of Turkey with descriptions of a new species and two new subspecies. Mitt Hamb Zool Mus Inst. 94:161-186

Bostanc1 D, Y1lmaz S, Polat, N. 2007. A research on age determination, length-weight relationship and condition factor of Rudd (Scardinius erythrophthalmus Linnaeus, 1758) population in Gölhisar Lake (Burdur). Türk Sucul Yaşam Derg. 5(8):99-107. [in Turkish]

Bostanc1 D, Y1lmaz S, Yılmaz M, Kandemir Ş, Polat N. 2009. Otolith dimensions-fish length relationships and some population parameters of pikeperch (Sander lucioperca 1., 1758) from Eğirdir Lake. Firat Uni J Sci. 21(1):9-17. [in Turkish]

Fricke R, Bilecenoglu M, Sari HM. 2007. Annotated checklist of fish and lamprey species (Gnathostoma and Petromyzontomorphi) of Turkey, including a Red List of threatened and declining species. Stuttgarter Beitr. Naturk. Sea A (Biologie). 706:1-172.

Geldiay R, Balık S. 2007. Türkiye tatlısu balıkları. VI. Baskı. İzmir: Ege Üniversitesi Basımevi 644 p. [in Turkish]

Innal D, Keskin N, Erk'akan F.2007. Distribution of Ligula intestinalis (L.) in Turkey. Turk J Fish Aquat Sci. 7(1):19-22.

Innal D. 2010. Population structures and some growth properties of three Cyprinid species [Squalius cephalus (Linnaeus, 1758); Tinca tinca (Linnaeus, 1758) and Alburnus escherichii Steindachner, 1897] living in Camkorupond (Ankara-Turkey). Kafkas Univ Vet Fak. 16 (Suppl-B):297-304. doi: $10.9775 / \mathrm{kvfd} .2010 .2346$

İlhan A, Balık S. 2008. Fish fauna of the inland waters in Western Black Sea Region. Ege J Fish Aqua Sci. 25(1):75-82. [in Turkish]

Kırankaya ŞG, Ekmekçi FG. 2007. Variations in growth properties of chub (Squalius cephalus, L., 1758) living in Gelingüllü Dam Lake. BAÜ FBE Derg. 9(2):125-134. [in Turkish]

Koutrakis ET, Tsikliras AC. 2003. Length-weight relationships of fishes from three Northern Aegean estuarine systems (Greece). J Appl Ichthyol. 19:258-260. doi: 10.1046/j.1439-0426.2003.00456.x

Kuru, M. 2004. Recent systematic status of inland water fishes of Turkey. GÜ, Gazi Eğt Fak Derg. 24(3):1-21. [in Turkish]

Le Cren ED. 1951. The length-weight relationship and seasonal cycle in gonad weight and condition in the perch (Perca fluviatilis). J Anim Ecol. 20(2):201-219.

Moutopoulos DK, Stergiou KI. 2002. Length-weight and length-length relationships of fish species from the Aegean Sea (Greece). J Appl Ichthyol. 18(3):200-203. doi: 10.1046/j.1439-0426.2002.00281.x

Özbek M, Öztürk MO. 2010. Investigations on Ligula intestinalis Plerocercoid L., 1758 Infection of Some Fishes from Dam Lake Kunduzlar (Kırka, Eskişehir). Türkiye Parazitol Derg. 34(2):112-117. [in Turkish]

Özuluğ M, Freyhof J. 2007. Alburnus demiri, a new species of bleak from Western Anatolia, Turkey (Teleostei: Cyprinidae). Ichthyol Explor Fres. 18(4):307-312.

Pervin MR, Mortuza MG. 2008. Notes on length-weight relationship and condition factor of fresh water fish, Labeo boga (Hamilton) (Cypriniformes: Cyprinidae). Univ J Zool Rajshahi Univ. 27:97-98.

Ricker WE. 1975. Computation and interpretation of biological statistics of fish populations. B Fish Res Board Can, 191. 382 p.

Simon KD, Mazlan AG. 2008. Length-weight and lengthlength relationships of Archer and Puffer fish species. The Open Fish Sci J. 2008(1):19-22. doi: 10.2174/1874401X00801010019

Soomro AN, Baloch WA, Jafri SIH, Suzuki H.2007. Studies on length-weight and length-length relationships of a catfish Eutropiichthyes vacha Hamilton (Schilbeidae: Siluriformes) from Indus river, Sindh, Pakistan. Caspian J Env Sci. 5(2):143-145. 
Tarkan AS, Özuluğ M, Gaygusuz Ö, Gaygusuz ÇG, Saç G. 2009. Length-weight relationships of six freshwater fishes from small streams flowing into Lake Sapanca, NW Turkey. J Appl Ichthyol. 25(2):230-231. doi: 10.1111/j.1439-0426.2008.01201.x

Yılmaz F, Barlas M, Kiriş E, Solak CN. 2003. An investigation on the fishes of Akçay (Muğla-Denizli). Sci Eng J Firat Uni. 15(2):147-155. [in Turkish]
Yılmaz S, Yazıcıoğlu O, Yılmaz M, Polat N. 2010. Length-weight and length-length relationships, and seasonal conditon factors of Cyprinus carpio L., 1758 and Tinca tinca (L., 1758) inhabiting Hirfanlı Dam Lake. SDÜ J Sci. 5(2):154-162. [in Turkish]

Yilmaz S, Y1lmaz M, Polat N. 2007. A research on agelength, age-weight and length-weight relationships of Silurus glanis L., 1758 population in Altinkaya Dam Lake (Samsun). SDÜ J Sci (E-Dergi). 2(1):18-26. [in Turkish] 